Article

\title{
Development and Stability Evaluation of Liquid Crystal-Based Formulations Containing Glycolic Plant Extracts and Nano-Actives
}

\author{
Andreza Rodrigues Ueoka and Carla Aparecida Pedriali Moraes * \\ Laboratório de Pesquisa, Tecnologia em Cosméticos, FATEC Diadema-Luigi Papaiz, 09931-390 Diadema, SP, \\ Brazil; andreza.rueoka@gmail.com \\ * Correspondence: capedriali@hotmail.com; Tel.: +55-011-4092-2328
}

Received: 9 January 2018; Accepted: 14 March 2018; Published: 22 March 2018

check for updates

\begin{abstract}
Emulsions are of great use in cosmetic formulations due to their stability. The aim of this work was to develop and assess organoleptic, physicochemical, and microscopic properties of four auto-emulsifiable oil-in-water formulations. Such formulations were developed containing 4.0\% cetearyl alcohol, dicetyl phosphate, and ceteth-10 phosphate (Formulation A), nano-actives obtained from safflower, coconut, and clove oils (Formulation B); a mixture of glycolic extracts from Centella asiatica leaves, Aesculus hippocastanum seeds, and Hamamelis virginiana leaves (Formulation C); association between the nano-actives and glycolic extracts described above (Formulation D). The formulations were trialed for 90 days under the normal stability test. The developed formulations were considered all stable and homogeneous, with liquid crystals possibly being formed. Organoleptic parameters and $\mathrm{pH}$ of Formulations $\mathrm{A}$ and $\mathrm{B}$ remained unchanged, but the color of Formulations $\mathrm{C}$ and $\mathrm{D}$ changed due to the natural color of the glycolic extracts used. It can be concluded that the formation of liquid crystals increased the stability of the formulations, and future tests should be carried out in order to assess the rheological properties and hydration potential of the developed formulations.
\end{abstract}

Keywords: liquid crystals; stability; nano-actives; emulsifiable cosmetics

\section{Introduction}

Emulsions can be defined as a homogeneous system made of an aqueous and an oil phase. In order for both phases to become a mixture, emulsifying agents are added to the formulation so that stability and homogeneity are achieved, maintaining both phases in a formulation system of equilibrium $[1,2]$.

The choice of raw materials to be used is essential if the emulsion is to have desirable characteristics in terms of consistency, stability, hydration, and the ability to improve skin aesthetics, among others. However, it is also important to define what the function and the applicability of the formulation will be [1].

The base used in the present study was a phosphate-derived auto-emulsifying base capable of forming liquid crystals. Liquid crystals are considered to be the "fourth state of matter", also called the mesomorphic state, and have properties of both solids and liquids [3]. Formulations that form liquid crystals are usually more chemicophysically stable, better protect bioactives against photo and thermodegradation, and better promote skin hydration by forming films on the stratum corneum [4].

The normal stability test is a predictive method used to assess the behavior of formulations when they are subjected for 90 days to adverse storage conditions, such as temperature variations and indirect exposure to sunlight, in order to determine whether any components of the formulation are incompatible and to predict the shelf-life of the formulation. Stability studies are vital in order to guarantee that a new formulation can remain stable, homogeneous, and safe for consumers [5]. 
The glycolic extracts used in this study were obtained from Centella asiatica, Indian chestnuts, and witch hazel; nano-actives were obtained from safflower, coconut, and clover oils. Such plants were chosen due to their properties that improve the overall aspect of skin when it is affected by gynoid lipodystrophy (simply known as cellulite). Cellulite is a disturbance of subcutaneous and conjunctive tissue fat tissues. Due to adipocyte hypertrophy, metabolic exchanges between intracellular and extracellular environments become compromised. There is transepidermal water loss, which prevents products from metabolism from being removed, and this product thus accumulates in tissues, causing alterations of blood circulation, lymphatic circulation, and venule permeability. These phenomena impair blood flow to the areas where cellulite develops [6-8].

Studies have already demonstrated that glycolic extracts from Centella asiatica, Indian chestnuts, and witch hazel have antioxidant and anti-inflammatory properties, stimulate collagen production improving skin regeneration, improve microvascular circulation of skin, are astringent, inhibit collagenase and elastase enzymes, and prevent transepidermal water loss. All of these actions are important for treatment of cellulite [9-12].

Nano-actives from safflower, clover, and coconut oils are thermogenic and are also antioxidant and anti-inflammatory, and they are capable of improving the aspect of skin when it is affected by cellulite. These nano-actives can improve a formulation's efficacy in treating cellulite, as nanoparticles can improve the protection of encapsulated bioactive compounds from degradation and improve the control of the release of bioactives. Nano-actives can also improve permeation through the skin [13-16].

In order to develop oil-in-water auto-emulsifiable formulations containing liquid crystal structures with glycolic extracts and nano-actives and assess their stability, preliminary and normal stability tests were carried out in order to assess their physicochemical properties $(\mathrm{pH}$, visual aspect, color, and scent). Polarized light microscopy was carried out in order to verify homogeneity and structural organization of the developed formulations. All tests were carried out according to the Cosmetic Products Stability Guide (ANVISA) [17,18].

\section{Materials and Methods}

\subsection{Formulation Development}

Four formulations were developed and tested. Formulation A contained only $4.0 \%$ Crodafos CES®emulsifying agent (cetearyl alcohol, dicetyl phosphate, and ceteth-10 phosphate) and $3.0 \%$ viscosity regulator Lanette $22 ®$ (behenyl alcohol) as a base, with no actives. The other formulations were developed with the same base, but with different actives. Formulation B had nano-actives from safflower, coconut, and clover oils; Formulation $\mathrm{C}$ had glycolic extracts from Centella asiatica and Hamamelis virginiana leaves and from Aesculus hippocastanum seeds; Formulation D had the components from Formulations $\mathrm{B}$ and $\mathrm{C}$ in association. The composition of each formulation is described in Table 1.

The oil-in-water emulsions were prepared initially by dispersing the aqueous phase components (water and acrylates/C10-30 alkyl acrylate crosspolymer) into disodium EDTA, glycerin, and propyleneglycol. In another recipient, the oil phase components were prepared (cetearyl alcohol, dicetyl phosphate, ceteth-10 phosphate, behenyl alcohol, butilhydroxitoluene, coconut oil, and isopropyl palmitate). Both aqueous and oil phases were then heated (heating plate 0261-22: Quimis ${ }^{\circledR}$, Diadema, Brazil) to $70-75^{\circ} \mathrm{C}$. Next, the oil phase was slowly added to the aqueous phase under high-torque mechanical stirring (Q250M1: Quimis $\left.{ }^{\circledR}\right)$ at $300 \mathrm{rpm}$ until the emulsion was completely homogenized. All other components were added after the emulsion had reached a $40{ }^{\circ} \mathrm{C}$ temperature. Formulations were stored at room temperature for a $24 \mathrm{~h}$ resting period and then were submitted to centrifuging tests and thermal stress tests. 
Table 1. Qualitative description of the developed formulations.

\begin{tabular}{|c|c|}
\hline INCI NAME & Function \\
\hline \multicolumn{2}{|c|}{ Formulations A, B, C, and D } \\
\hline $\begin{array}{c}\text { cetearyl alcohol, dicetyl phosphate, and ceteth-10 phosphate } \\
\text { behenyl alcohol } \\
\text { butilhydroxitoluene } \\
\text { glycerin } \\
\text { isopropyl palmitate } \\
\text { aqua } \\
\text { acrylates/C10-30 alkyl acrylate crosspolymer } \\
\text { propyleneglycol } \\
\text { disodium EDTA } \\
\text { methylisothiazolinone and phenoxyethanol } \\
\text { triethanolamine } \\
\text { coconut oil } \\
\text { Helianthus annus seed oil } \\
\text { almond oil }\end{array}$ & $\begin{array}{c}\text { emulsifying and conditioning system } \\
\text { emulsion stabilizer and emollient } \\
\text { Antioxidant } \\
\text { Humectant } \\
\text { Emollient } \\
\text { Solvent } \\
\text { viscosity increasing agent } \\
\text { Humectant } \\
\text { chelating agent } \\
\text { antimicrobial agent } \\
\text { pH buffer } \\
\text { antioxidant, emollient } \\
\text { Emollient } \\
\text { Emollient }\end{array}$ \\
\hline \multicolumn{2}{|l|}{ Actives } \\
\hline $\begin{array}{l}\text { water, Carthamus tictorius seed oil, Cocos nucifera oil, Eugenia } \\
\text { caryophyllus bud oil, phenoxyethanol, methylisothiazolinone }\end{array}$ & anti-cellulite actives (Formulation B) \\
\hline $\begin{array}{c}\text { glycerin, alcohol, Centella asiatica leaf, Aesculus hippocastanum } \\
\text { seed, Hamamelis virginiana leaf extract }\end{array}$ & $\begin{array}{l}\text { anti-cellulite actives that prevent } \\
\text { vasoconstriction and increase skin elasticity } \\
\text { (Formulation C) }\end{array}$ \\
\hline bioactives from Formulations $\mathrm{B}$ and $\mathrm{C}$ in association & Formulation D \\
\hline
\end{tabular}

\subsection{Preliminary Stability Evaluation (PSE)}

All stability tests were carried out according to ANVISA Stability Guidelines, 2004 [17]. Preliminary stability evaluation was performed using a rapid response indicator that readily shows whether any of the raw materials used are incompatible and whether any phase separation will occur after the emulsions are prepared.

\subsubsection{Centrifuging Test}

The centrifuging test was carried out in order to assess possible formulation instabilities, as they are indicators of incoming phase separation, coalescence, precipitation, and sedimentation. A total of $5 \mathrm{~g}$ of each formulation was placed into respective centrifuge tubes; next, the tubes were centrifuged (Q222TI: Quimis ${ }^{\circledR}$, Diadema, Brasil) at room temperature $\left(22.0 \pm 2.0^{\circ} \mathrm{C}\right)$ at $3000 \mathrm{rpm}$ for $30 \mathrm{~min}$.

\subsubsection{Thermal Stress Test}

The thermal stress test was carried out in order to assess the stability and compatibility of components used in the developed formulations. A total of $5 \mathrm{~g}$ of each formulation was placed into respective test tubes; next, the tubes were placed into a thermostatic water bath (150/30D: Lucadema ${ }^{\circledR}$, São José do Rio Preto, Brasil) at temperatures of 40,50 , and $60^{\circ} \mathrm{C}$. After $1.5 \mathrm{~h}$, after room temperature had been reached $\left(25.0 \pm 2{ }^{\circ} \mathrm{C}\right)$, the formulations were assessed regarding the following parameters: visual aspect, scent, and surface drying.

\subsection{Normal Stability Test}

Formulations considered stable after being subjected to PSE were then assessed under normal stability tests (NSTs) after a $24 \mathrm{~h}$ resting period. A total of $15 \mathrm{~g}$ of each formulation was placed into plastic recipients with $20 \mathrm{~g}$ capacities, which were then closed and sealed. The recipients remained in different temperature conditions for 90 days. Standard control samples were kept at room temperature $\left(22.0 \pm 2.0^{\circ} \mathrm{C}\right)$ protected from light and humidity. All analyses were carried out at room temperature.

Experimental parameters used for this test were as follows: 
- $\quad-10.0 \pm 0.5^{\circ} \mathrm{C}$ (freezer CRC30: Consul ${ }^{\circledR}$, São Paulo, Brazil);

- $\quad 5.0 \pm 0.5^{\circ} \mathrm{C}$ (refrigerator Whirlpool BR562: Brastemp ${ }^{\circledR}$, São Paulo, Brazil);

- $\quad 50.0 \pm 0.5^{\circ} \mathrm{C}$ (incubator 031-7M-12: Quimis ${ }^{\circledR}$, Diadema, Brazil);

- $\quad 25.0 \pm 2{ }^{\circ} \mathrm{C}$ (room temperature-Indirect exposure to sunlight).

Samples were assessed at Days 1, 30, 60, and 90. The NST provides valuable information regarding formulation behavior when they are subjected to different temperatures in order to assess whether any sort of phase separation, active precipitation, viscosity alterations, and solubility changes take place [5].

\section{4. $p H$ Assessment}

The determination of $\mathrm{pH}$ also predicts formulation stability throughout their storage period. A total of $1.0 \mathrm{~g}$ of each sample was placed into a $9.0 \mathrm{~mL}$ portion of purified water. The samples were then homogenized, and their $\mathrm{pH}$ was assessed at room temperature (Q400 AS: Quimis ${ }^{\circledR}$, Diadema, Brazil). Tests were carried out in duplicates for each formulation [17].

\subsection{Polarized Light Microscopy}

The polarized light microscope has a polarizing filter and an analyzing filter. The polarizing filter is placed under the sample, while the analyzing filter is placed on top of it. This mechanism allows for analysis under cross-polarized light with no transmitted light. Under such lighting conditions, birefrective liquid crystals (with the exception of cubic crystals) can be properly assessed regarding their structure $[19,20]$. Analyses were carried out using a petrographic microscope BX41TF (Olympus, Tokyo, Japan) using a $5 \times$ lens.

This test was carried out in order to assess the emulsion microstructure and the formation of liquid-crystal phases [4]. A total of $0.2 \mathrm{~g}$ of all samples were placed in glass slides and assessed by polarized light microscopy at Days 0 and 90.

\subsection{Parameters and Criteria Used on Stability Tests}

Formulations were tested for possible physicochemical alterations. Parameters tested included physical aspect, color, scent, and $\mathrm{pH}$. Analyses were carried out at room temperature $\left(22 \pm 2{ }^{\circ} \mathrm{C}\right)[17,21]$. Overall sample parameters should be similar to those observed for standard control samples, which were kept at room temperature. Two final classifications were used: no modifications (NM) and slightly modified (SM). Slight changes are accepted only for samples kept at extreme temperature conditions, namely at -10 and at $50{ }^{\circ} \mathrm{C}$. Alterations of $\mathrm{pH}$ of $\pm 0.5 \%$ of the initial value of the samples kept at room temperature were considered acceptable.

\subsection{Organoleptic Parameters}

Organoleptic parameters assessed were visual aspect, color, and scent of the formulations. These tests were carried out in order to verify whether there would be any sort of phase separation, brightness changes, and precipitation of actives. All tested samples were compared to standard control samples, which were kept at room temperature protected from direct sunlight and humidity. Samples were classified as follows [17]:

- (M) modified;

- $\quad(\mathrm{SM})$ slightly modified;

- (NM) no modifications regarding visual aspect, color, and scent.

\section{Results and Discussion}

While emulsions are widely used in cosmetic formulations, they have the disadvantage of suffering from low physicochemical stability. Therefore, when an emulsion is developed, physicochemical stability 
should first be achieved, and only then should other parameters, such as consistency, spreadability, hydrating capability, film formation, and its ability to improve skin aesthetic appearance, be determined. Next, safety and efficacy tests should be carried out in order to guarantee that the cosmetic formulation poses no risk to consumers. All tests carried out in the present study were in accordance with the ANVISA Stability Guidelines [17,18,22].

One study aimed at developing oil-in-water emulsions with a lamellar structure for their liquid-crystal phases used Crodafos CES®(cetearyl alcohol (and) dicetyl phosphate (and) ceteth-10 phosphate) at a 5.0\% concentration in association with rutin succinate and chemical and physical filters. One of the aims was to assess the stability conferred by the base used associated with bioactives [21].

\subsection{Preliminary Stability Testing}

After $24 \mathrm{~h}$ of their preparation, the $\mathrm{pH}$ of the formulations were assessed and preliminary stability tests were carried out (centrifuging and thermal stress tests). All formulations remained stable throughout the preliminary stability tests, as no phase separation (coalescence) occurred, and no actives were degraded at the tested temperatures which ranged from 40 to $60^{\circ} \mathrm{C}$. The emulsions also had no modifications regarding visual aspect, color, or scent. No surface drying of the emulsions was detected, which could have happened had the amount of humectants used been insufficient. Therefore, all samples were considered eligible for further normal stability tests.

\subsection{Normal Stability Tests}

All samples were placed into plastic recipients, which were closed and sealed. Recipients were kept at different storage conditions for 90 days: exposure to sunlight, refrigerator, freezer, and incubator. No relevant changes occurred regarding to $\mathrm{pH}$ changes, as shown in Table 2.

Table 2. Accelerated stability profile of Formulations A, B, C, and D.

\begin{tabular}{cccccc}
\hline Formulation & $\mathrm{pH}(\mathbf{t} \mathbf{0})$ & $\mathrm{pH}\left(\mathbf{t} \mathbf{3 0}{ }^{*}\right)$ & $\mathrm{pH}(\mathbf{t} 60 *)$ & $\mathrm{pH}\left(\mathbf{t 9 0}{ }^{*}\right)$ & Stability \\
\hline $\mathrm{A}$ & 6.1 & 6.3 & 6.1 & 6.3 & stable \\
$\mathrm{B}$ & 6.1 & 6.0 & 5.9 & 5.9 & stable \\
$\mathrm{C}$ & 6.1 & 6.1 & 6.2 & 6.2 & stable \\
$\mathrm{D}$ & 5.9 & 6.1 & 6.2 & 6.2 & stable \\
\hline
\end{tabular}

* After a time period of $24 \mathrm{~h}(\mathrm{t} 0), 30$ days (t30), 60 days (t60), and 90 days (t90). A-base formulation containing only $4.0 \%$ Crodafos CES $^{\circledR}$ (cetearyl alcohol, dicetyl phosphate, and ceteth-10 phosphate); B-formulation containing nano-actives from safflower, coconut, and clover oils; $\mathrm{C}$-formulation containing glycolic extracts of Centella asiática and Hamamelis virginiana leaves and Aesculus hippocastanum seeds; D-formulation containing an association of nano-actives and glycolic extracts.

Organoleptic parameters of Formulations A and B suffered no modifications at all (NM), while only the scent and visual aspect of Formulations C and D remained unchanged (NM), as their color suffered modifications (M), probably due to the natural color of the glycolic extracts used.

\subsection{Microscopic Analysis of the Formulations}

Emulsions were analyzed microscopically after $24 \mathrm{~h} \mathrm{(t0)}$ and after 90 days (t90) of their initial preparation. Such analyses were carried out in order to assess homogeneity, molecule organization, and the possible formation of liquid crystals. Microscopy images are shown in Figure 1.

It was observed that all formulations tested formed a liquid-crystal phase. In addition, the formulations containing nano-actives or glycolic extracts had similar characteristics and high molecular organization, which is important for formulation stability. Other studies have also demonstrated how advantageous it is for formulations to form liquid-crystal phases, as they improve the formulation in several aspects: there is increased water retention in the skin corneum stratum, which increases hydrating, increases viscosity due to molecular reorganization, increases permeability, and prolongs bioactive release $[4,20,23,24]$. 


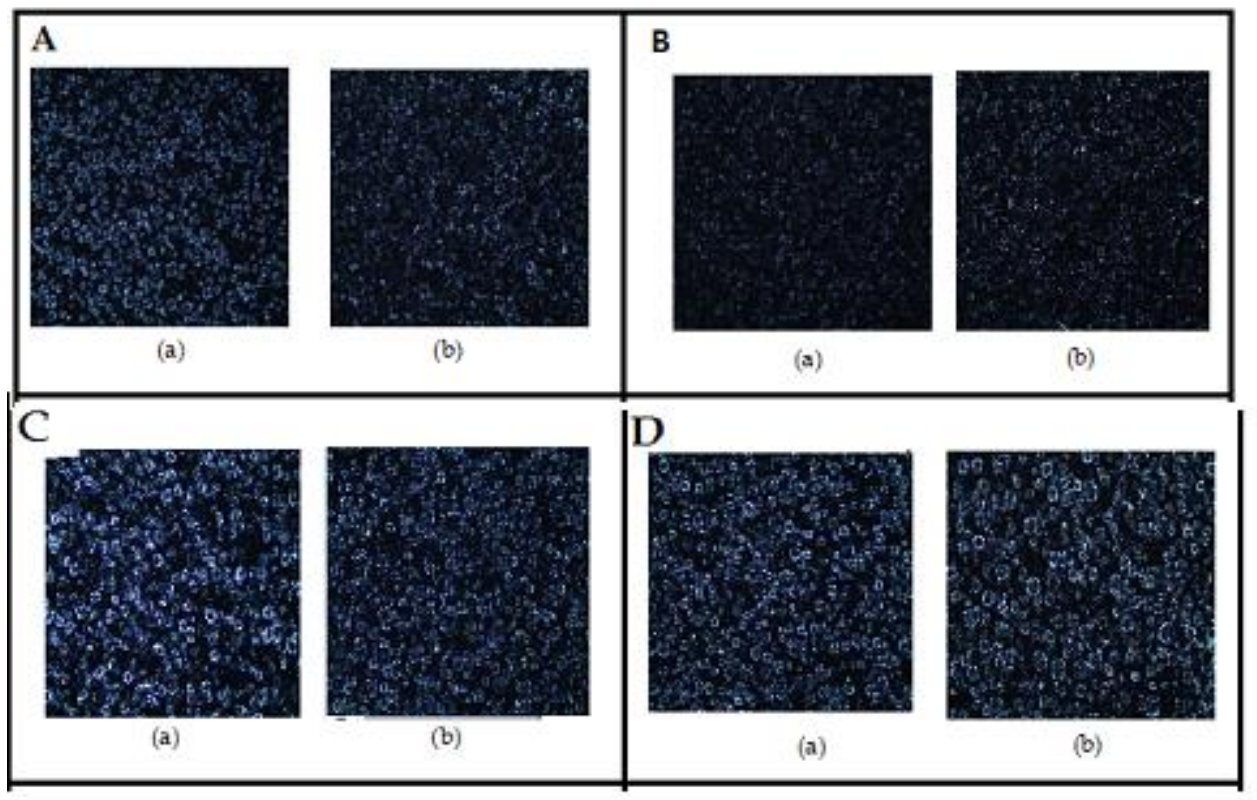

Figure 1. Formation of the liquid-crystal structure in Formulations A, B, C, and D (a) after $24 \mathrm{~h}(\mathrm{t} 0)$ and (b) after 90 days (t90). (A) — base formulation containing only $4.0 \%$ Crodafos CES ${ }^{\circledR}$ (cetearyl alcohol, dicetyl phosphate, and ceteth-10 phosphate); (B)-formulation containing nano-actives from safflower, coconut, and clover oils; (C) - formulation containing glycolic extracts of Centella asiática and Hamamelis virginiana leaves and Aesculus hippocastanum seeds; (D)_formulation containing an association of nano-actives and glycolic extracts.

\section{Conclusions}

All formulations tested had similar stability parameters, barred acceptable color changes for Formulations $\mathrm{C}$ and D due to the use of glycolic extracts. All formulations formed liquid-crystal phases, which contributes to formulation stability. Thus, in terms of cost viability, formulations containing glycolic extracts are preferable, as such formulations, compared to the other formulations, remained similarly stable throughout all testing periods. However, in terms of efficacy, further studies should be carried out in order to verify which formulation is most suitable for possible cellulite treatment. The rheological parameters and hydration potential of these formulations should be assessed in the future.

Author Contributions: Andreza Rodrigues Ueoka and Carla Aparecida Pedriali Moraes analyzed the data; Andreza Rodrigues Ueoka wrote the final manuscript and Carla Aparecida Pedriali Moraes revised it.

Conflicts of Interest: The authors declare no conflict of interest.

\section{References}

1. Correa, M. Cosmetologia—Ciência e Técnica, 1st ed.; Medfarma: São Paulo, Brasil, 2012; p. 492.

2. Tadros, T.F. Emulsion Formation and Stability, 1st ed.; Wiley-VCH: Alemanha, Germany, 2013; p. 252.

3. Neto, A.M.F.; Salinas, S.R.A. The Phisics of Lyotropic Liquid Crystals: Phase Transitions and Structural Properties, 1st ed.; Oxford University Press: New York, NY, USA, 2005; p. 301.

4. Silva, S.A.M.; Rigon, R.B.; Valarini, M.F.; Chorilli, M.; Leonardi, G.R. Análise da influência do agente umectante na estabilidade reológica e avaliação de cristais líquidos em formulações cosméticas. Rev. Bras. Farm. 2013, 3, 199-210.

5. Baby, A.R.; Maciel, C.P.M.; Zague, V.; Kaneko, T.M.; Consiglieri, V.O.; Velasco, M.V.R. Estabilidade de produtos de aplicação tópica: Ensaios aplicados aos produtos cosméticos e dermatológicos emulsionados. Int. J. Pharm. Compd. 2004, 6, 130-139.

6. Bacelar, V.C.F.; Vieira, M.E.S. Importância da vacuoterapia no fibro edema gelóide. Fisioter Bras. 2006, 7, $440-443$. 
7. Draelos, Z.D. Cosmecêuticos, 2nd ed.; Elsevier: Rio de Janeiro, Brasil, 2009; p. 276.

8. Leonardi, G.R.; Chorilli, M. Celulite_Prevenção e Tratamento, 1st ed.; Pharmabooks: São Paulo, Brasil, $2010 ;$ p. 118.

9. Yarnell, E. Botanical Medicines for Dermatologic Conditions. Altern. Complement. Ther. 1999, 5, $106-109$. [CrossRef]

10. Ramos, M.F.D.S.; Santos, E.P.; Silva, A.B.; Leitão, A.C.; Dellamora-Ortiz, G.M. Avaliação fototoxica e screening mutagênico de extratos de propolis, Aloe spp. e Hamamelis virginiana. Rev. Ciênc. Farm. Basica Apl. 2005, 26, 105-111.

11. Mukherjee, P.K.; Maity, N.; Sarkar, B.K. Bioactive compounds from natural resources against skin aging. Phytomedicine 2011, 19, 64-73. [CrossRef] [PubMed]

12. Dudeke-Makuch, M.; Studzinska-Sroka, E. Horse chestnut-Efficacy and safety in chronic venous insufficiency: An overview. Rev. Bras. Farmacogn. 2015, 25, 533-541. [CrossRef]

13. Marina, A.M.; Man, Y.C.; Nazimah, S.A.H.; Amin, I. Chemical Properties of Virgin Coconut Oil. J. Am. Oil Chem. Soc. 2009, 86, 301-307. [CrossRef]

14. Affonso, R.S.; Rennó, M.N.; Slana, G.B.C.A.; França, T.C.C. Aspectos Químicos e Biológicos do Óleo Essencial de Cravo da Índia. Rev. Virtual Quim. 2012, 4, 146-161.

15. Toma, W.; Guimarães, L.L.; Brito, A.R.M.S.; Santos, A.R.; Cortez, F.S.; Pusceddu, F.H.; Cesar, A.; Júnior, L.S.; Pacheco, M.T.T.; Pereira, C.D.S. Safflower oil: An integrated assessment of phytochemistry, antiulcerogenic activity, and rodentand environmental toxicity. Rev. Bras. Famacogn. 2014, 24, 538-544. [CrossRef]

16. Ramos, B. Quebrando paradigmas da nanotecnologia. CET 2015, 27, 50-52.

17. The Brazilian Health Regulatory Agency (ANVISA). Guia de Estabilidade de Produtos Cosméticos; Ministério da Saúde, ANVISA: Brasília, Brazil, 2004. Available online: http:/ /www.anvisa.gov.br/divulga/public/series/ cosmeticos.pdf (accessed on 11 September 2016).

18. The Brazilian Health Regulatory Agency (ANVISA). Guia de Controle de Qualidade de Produtos Cosméticos; Ministério da Saúde, ANVISA: Brasília, Brazil, 2008. Available online: http/ /www.anvisa.gov.br/cosmeticos/ material/guia_cosmetico.pdf (accessed on 9 August 2016).

19. Carlton, R.A. Polarized light microscopy. In Pharmaceutical Microscopy, 1st ed.; Springer: New York, NY, USA, 2011; pp. 7-64.

20. Silva, S.A.M.; Silva, M.M.; Leonardi, G.R.; Baillo, R.P.V.; Valarina, M.F.C. Cristais líquidos aplicados à cosmetologia. CET 2015, 27, 52-57.

21. Pedriali-Moraes, C.A.; Arêas, E.P.G.; Velasco, M.V.R. Assessment of functional stability of photoprotective formulations containing rutin succinate. Cosmetics 2017, 4, 1-14.

22. Ansel, H.C.; Popovich, N.G.; Alen, L.V., Jr. Farmacotécnica: Formas Farmacêuticas E Sistemas de Liberação de Fármacos, 6th ed.; Premier: São Paulo, Brasil, 2000; p. 568.

23. Iwai, H.; Fukasawa, J.; Suzuki, T. A liquid crystal application in skin care cosmetics. Int. J. Cosmet. Sci. 1998, 20, 87-102. [CrossRef] [PubMed]

24. Silva, S.A.M.; Valarini, M.F.C.; Chorilli, M.; Venturini, A.; Leonardi, G.R. Atividade antioxidante do extrato seco de cacau orgânico (Theobroma cacao)—Estudo de estabilidade e teste de aceitação de cremes acrescidos deste extrato. Rev. Ciênc. Farm. Basica Apl. 2013, 34, 493-501.

(C) 2018 by the authors. Licensee MDPI, Basel, Switzerland. This article is an open access article distributed under the terms and conditions of the Creative Commons Attribution (CC BY) license (http:// creativecommons.org/licenses/by/4.0/). 